\title{
Paratesticular Solitary Fibrous Pseudotumor and a Brief Literature Review
}

\author{
Paratestiküler Soliter Fibröz Psödotümör ve Kısa Literatür Derlemesi
}

\author{
(D) Ali Furkan Batur1, (D) Mehmet Kaynar¹, (D) Zeliha Esin Çelik2, (D) Serdar Göktaş1 \\ 1Selçuk University Faculty of Medicine, Department of Urology, Konya, Turkiye \\ 2Selçuk University Faculty of Medicine, Department of Pathology, Konya, Turkiye
}

\begin{abstract}
A 19-year-old male patient was admitted to our clinic with a left-sided scrotal painless mass. Ultrasonography of the scrotum revealed a paratesticular mass arising from the left testicular sac. Surgical excision of the mass was performed. Intraoperative frozen section evaluation revealed a benign fibrous tumor. Microscopically, the specimen was composed of eosinophilic cytoplasmic tumor cells with spindle nucleus on a fibrous connective tissue ground. It is important to diagnose correctly this rare condition preoperatively or intraoperatively to avoid unnecessary orchiectomies. We present this case report to increase awareness and knowledge with the support of a brief literature review.
\end{abstract}

Keywords: Testicular neoplasms, Pseudotumor, Inflammatuary, Orchiectomy

Öz

On dokuz yaşında erkek hasta sol skrotal bölgede büyüyen ağrısız kitle nedeniyle polikliniğimize başvurdu. Skrotal ultrasonografi, sol testiküler bölgeden köken alan paratestiküler kitle olduğunu gösterdi. Kitleye eksizyon yapıldı. Kitlenin frozen histopatolojik değerlendirmesi benign fibröz bir tümör olduğunu gösterdi. Mikroskobik olarak spesimen fibröz bağ doku zemini üzerinde yer alan iğsi nükleusa sahip olan eozinofilik sitoplazmik tümör hücrelerinden oluşmaktaydı. Bu nadir durumun preoperatif veya intraoperatif olarak tanısının konulması gereksiz orşiektomilerin önlenmesi için önemlidir. Biz bu olgu sunumu ile paratestiküler fibröz psödotümör olan bir olguyu kısa literatür derleme desteği ile sunarak bu konuda ki farkındalığı ve bilgiyi artırmayı amaçladık

Anahtar Kelimeler: Testis tümörleri, Psödotümör, Enflamatuvar, Orşiektomi

\section{Introduction}

Paratesticular fibrous pseudotumors (PFPs) are rare lesions thought to be reactive fibrous inflammatory hyperplasia. They originates from the tunica vaginalis, epididymis, tunica albuginea, or spermatic cord (1). A PFP was first described by Balloch in 1904 (2). PFPs constitute approximately 6\% of all paratesticular lesions. Although they are common in the third decade of life, PFPs can be seen in all age groups. The pathogenesis and etiology remain unclear, however, these lesions usually develop after infection and/or trauma (3). Patients mostly present with painless scrotal masses apart from the testicle. Ultrasonography (USG) is often sufficient to determine the lesions, and testicular tumor markers are useful to exclude malignancy. However, distinguishing these lesions from malignant lesions on the basis of clinical and radiological findings is still challenging. Orchiectomies have been reported previously for the treatment of PFPs. Frozen section evaluation of the tumor is mostly recommended to avoid unnecessary orchiectomy (4).

Here, we present a case of PFP to remind this uncommon condition, and, also to increase the awareness and knowledge with the support of a brief literature review.

\section{Case Report}

The complaint of our 19-year-old male patient was a painless scrotal mass. There was no history of trauma and/or

Correspondence: Ali Furkan Batur MD, Selçuk University Faculty of Medicine, Department of Urology, Konya, Turkiye E-mail: alifurkanbatur@gmail.com ORCID-ID: orcid.org/0000-0001-7945-7326

Received: 28.02.2019 Accepted: 19.03.2019

Cite this article as: Batur AF, Kaynar M, Çelik ZE, Göktaş S. Paratesticular Solitary Fibrous Pseudotumor and a Brief Literature Review. J Urol Surg 2019;6(4):325-327.

๑Copyright 2019 by the Association of Urological Surgery / Journal of Urological Surgery published by Galenos Publishing House. 
epididymoorchitis. A round-shaped firm mass apart from the left testicle was detected at the left side of the scrotum. There were no enlarged inguinal lymph nodes. His laboratory tests, including tumor markers for testicular cancer, were normal (alpha-fetoprotein: $1.09 \mu \mathrm{g} / \mathrm{mL}$, human chorionic gonadotropin: $0.1 \mathrm{U} / \mathrm{L}$, lactate dehydrogenase:164 U/L). Color Doppler USG of the scrotum revealed a paratesticular mass measuring $5 \times 4 \times 4 \mathrm{~cm}$ arising from the left testicular sac. Also, there were very dense calcification areas in the mass.

The mass was excised through left inguinal incision. A solid, well-encapsulated mass originating from the epididymis was found during the surgical procedure. It was enucleated from the left testis, epididymis, and spermatic cord without harming them (Figure 1).

The frozen section evaluation of the mass revealed a benign fibrous tumor. The gross specimen revealed a dirty-white firm mass with hemorrhage and degeneration areas on the cut section (Figure 1).

Microscopically, the specimen was composed of eosinophilic cytoplasmic tumor cells with spindle nuclei on a fibrous connective tissue ground (HEX100-200). Immunohistochemistry demonstrated positive staining for vimentin and pancytokeratin and negative for CD34, desmin, beta catenin, and smooth muscle actin (SMA). Also, based on our Ki-67 staining, the cell proliferation rate was low (Figure 2).

No recurrences were detected at 6-month follow-up.

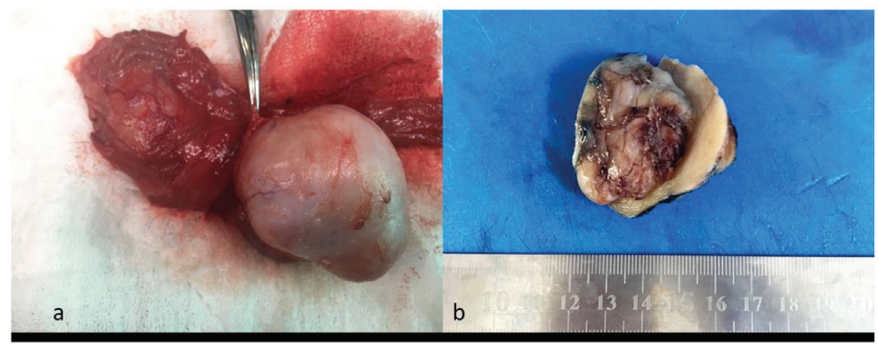

Figure 1. The gross specimen revealed dirty-white firm mass with some hemorhage and degeneration areas on the cut section

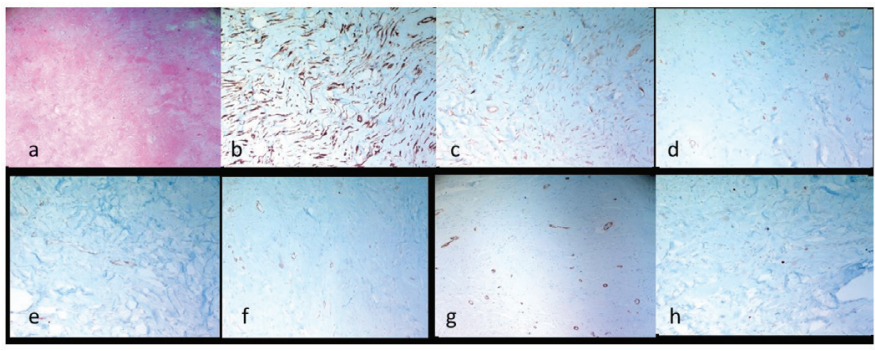

Figure 2. a) Eosinophilic cytoplasmic tumor cells with spindle nucleus on a fibrous connective tissue ground; $b, c)$ Positive staining results for vimentin and pancytokeratin; $d-g$ ) Negative staining results for CD34, desmin, beta katenin, and smooth muscle actin; h) Low cell proliferation rate with Ki-67 staining

\section{Discussion}

A little more than 200 PFP cases have been reported. However, underreporting should be considered because of the complexity of the terminology and, also, confusing PFP with other pathologies. Various assigned names have been used for identification of this rare lesion (3). PFPs can be seen in many age groups. The peak incidence is in young adulthood (2). Therefore, PFP can be overtreated with orchiectomy with the testicular neoplasm prediagnosis.

PFPs mostly originate from the tunica vaginalis (2). PFP was originating from the epididymis in our case.

Typical clinical presentation of PFP is slow-growing painless scrotal nodules. The diagnosis is mostly made by USG. Usually, the sonographic pattern is homogeneously hypoechoic lesion with sharp margins apart from the testicle. Magnetic resonance imaging (MRI) can be used to confirm the diagnosis. Typical findings on the MRI are intermediate signal density on T1weighed and low signal density on T2-weighted images (5). Also, heterogeneous gadolinium enhancement can be seen. We confirmed the diagnosis only by USG in our case.

Typical histopathological findings of PFP are plasma cells and lymphocytes interspersed between collagen bundles in hyalinized tissue (2). Miyamoto et al. (6) subdivided PFPs into 3 categories on the basis of their 13 cases: (1) plaque-like; (2) inflammatory sclerotic; and (3) myofibroblastic (6). Our case can be classified as group 1 according to this categorization. The differential diagnosis of PFPs includes solitary fibrous tumor, mesothelioma, neurofibromatosis, and leiomyoma. Histopathologic features (necrosis, pleomorphism, and increased mitotic activity), mostly specific to malignancies, are not found in PFPs. These features were not present in our case either.

Staining with vimentin, muscle-specific actin, and SMA give positive results. On the other hand, staining with carcinoembryonic antigen, cytokeratin, S-100 protein, desmin, CD31, melanin-A, CD34, and inhibin give negative results. Ki67 staining shows low cell proliferation in PFPs. Ultrastructural evaluation has supported myofibroblastic differentiation in some of the case reports $(2,6)$. Staining with vimentin and pancytokeratin were positive; and negative with CD34, desmin, beta catenin, and SMA in our case. Also, the cell proliferation rate with $\mathrm{Ki}-67$ staining was low in our case.

There are new studies claiming that PFPs can be related to immunoglobulin G4 (IgG4)-related sclerosing disorders $(2,7)$. Preoperative elevated serum IgG4 levels support this diagnosis. We did not study serum Ig profiles and/or histologically $\lg G 4$ staining either. 
It is important to diagnose this rare pathology preoperatively or intraoperatively correctly to avoid unnecessary orchiectomies. Preoperative scrotal USG is the mainstay diagnostic tool, and MRI can be used in cases of doubt. Frozen section examination can be made if there is still doubt.

\section{Ethics}

Informed Consent: Consent form was filled out by the participant.

Peer-review: Internally peer-reviewed.

\section{Authorship Contributions}

Concept: M.K., S.G., Design: S.G., Data Collection and/ or Processing: A.F.B., Analysis and/or Interpretation: A.F.B., Literature Research: A.F.B., Z.E.Ç., Writing: A.F.B.

Conflict of Interest: No conflict of interest was declared by the authors.

Financial Disclosure: The authors declared that this study received no financial support.

\section{References}

1. Zhang Z, Yang J, Li M, Cai W, Liu Q, Wang T, et al. Paratesticular fibrous pseudotumor: a report of five cases and literature review. Front Med. 2014;8(4):484-48.

2. Dieckmann KP, Struss WJ, Frey U, Nahler-Wildenhain M. Paratesticular fibrous pseudotumor in young males presenting with histological features of IgG4-related disease: Two case reports. J Med Case Rep [Internet]. 2013;7(1):1. Available from: Journal of Medical Case Reports

3. Akbar SA, Sayyed TA, Jafri SZH, Hasteh F, Neill JSA. Multimodality imaging of paratesticular neoplasms and their rare mimics. Radiographics. 2003;23(6):1461-1476

4. Kodama H, Hatakeyama $\mathrm{S}$, Matsumoto $T$, Tanaka $T$, Horiguchi H, Kubota $Y$, et al. A Case of Fibrous Pseudotumor in the Scrotum: Challenge for Diagnosis and Testicular Preservation. Case Rep Urol [Internet]. 2018;2018(c):5-8. Available from: https://doi.org/10.1155/2018/6904827

5. Krainik A, Sarrazin JL, Camparo P, Vincendeau S, Houlgatte A, Cordoliani YS. Fibrous pseudotumor of the epididymis: Imaging and pathologic correlation. Eur Radiol. 2000;10(10):1636-1638.

6. Miyamoto $\mathrm{H}$, Montgomery EA, Epstein Jl. Paratesticular fibrous pseudotumor: A morphologic and immunohistochemical study of 13 cases. Am J Surg Pathol. 2010;34(4):569-574.

7. Bösmüller $\mathrm{H}$, Von Weyhern $\mathrm{CH}$, Adam $\mathrm{P}$, Alibegovic $\mathrm{V}$, Mikuz $\mathrm{G}$, Fend $\mathrm{F}$. Paratesticular fibrous pseudotumor-an IgG4-related disorder? Virchows Arch. 2011;458(1):109-113. 